\title{
PELATIHAN DIGITALISASI DESAIN BATIK DAN MEDIA PROMOSI ONLINE UNTUK SANTRI PONDOK PESANTREN BABUSSALAM JOMBANG
}

\author{
Kusuma Wardhani Mas'udah¹), Nur Aini Fauziyah'2), Euis Nurul Hidayah ${ }^{3)}$ \\ 1)Teknik Mesin, Fakultas Teknik, Universitas Pembangunan Nasional "Veteran" Jawa Timur, 60294, Indonesia \\ 2)Teknik Kimia, Fakultas Teknik, Universitas Pembangunan Nasional "Veteran" Jawa Timur, 60294, Indonesia \\ ${ }^{3)}$ Teknik Lingkungan, Fakultas Teknik, Universitas Pembangunan Nasional "Veteran" Jawa Timur, 60294, Indonesia \\ Corresponding author : kusuma.w.fisika@upnjatim.ac.id \\ E-mail : euisnh.tl@upnjatim.ac.id
}

Diterima 24 Juli 2021, Direvisi 01 Agustus 2021, Disetujui 02 Agustus 2021

\begin{abstract}
ABSTRAK
Program Pengabdian Kepada Masyarakat ini memiliki tujuan: 1) peningkatan kemampuan kewirausahaan santriwan-santriwati Pondok Pesantren Babussalam melalui potensi kemampuan membuat Desain Batik digital dan Blogspot, 2) peningkatan kesejahteraan santri dan pesantren yang lebih baik melalui pemanfaatan sumber daya yang memiliki nilai ekonomi, 3) terbentuknya usaha ekonomi pesantren dan kelembagaan yang terstruktur melalui unit usaha pesantren, 4) peningkatan kemampuan santri dan pesantren untuk melakukan diversifikasi produk. Kegiatan ini menggunakan dua pendekatan yaitu pendekatan pelatihan dan pendampingan. Pendekatan pelatihan meliputi : 1) Pelatihan Kewirausahaan; 2) Pelatihan dasar-dasar desain grafis, 3) Pelatihan digitalisasi desain batik, 4) Pelatihan pemanfaatan blogspot untuk media pemasaran. Sedangkan metode pendampingan meliputi :1) Pendampingan penguatan sumber daya manusia melalui peningkatan pemasaran, manajemen, dan motivasi berwirausaha; 2) Pendampingan pembentukan kelembagaan Unit Usaha Pesantren. Diharapkan hasil dari kegiatan pengabdian kepada masyarakat ini adalah terwujudnya unit usaha pesantren dalam bidang batik dengan motif kekhasan yang diangkat dari motif sains, semakin meningkatnya jiwa wirausaha dan manajemen pada santri, serta peningkatan kemampuan pemasaran melalui media online.
\end{abstract}

Kata kunci: corelDraw; blogspot; kewirausahaan; pendampingan.

\begin{abstract}
This Community Service Program has the following objectives: 1 ) increasing the entrepreneurial abilities of the Babussalam Islamic Boarding School students through the potential ability to create digital Batik Designs and Blogspots, 2) improving the welfare of students and pesantren through the utilization of resources that have economic value, 3) formation of the pesantren economic business and structured institutions through pesantren business units, 4 ) increasing the ability of santri and pesantren to diversify products. This activity uses two approaches, namely the training and mentoring approach. The training approach includes: 1) Entrepreneurship Training; 2) Basic graphic design training, 3) Batik design digitization training, 4) Training on the use of Blogspot for marketing media. While the mentoring methods include: 1) Assistance in strengthening human resources through increased marketing, management, and entrepreneurial motivation; 2) Assistance in the institutional formation of the Islamic Boarding School Business Unit. It is hoped that the results of this community service activity are the realization of a pesantren business unit in the field of batik with a unique motif that is lifted from a scientific motif, increasing entrepreneurial spirit and management in students, as well as increasing marketing skills through online media.
\end{abstract}

Keywords: corelDraw; blogspot; entrepreneurship; accompaniment.

\section{PENDAHULUAN}

Pesantren merupakan Lembaga pendidikan informal berbasis agama islam yang mempunyai peran sebagai pembentukan moral dan kemandirian santri dalam kehidupan sehari-hari melalui pembinaan dan pemberdayaan yang terus didorong kualitasnya. Berasal dari kata santri, pesantren dapat diartikan sebagai tempat bagi para santri untuk menuntut ilmu (Senoprabowo dkk., 2019). Sedangkan orang awam mengenal pesantren adalah hal-hal yang berhubungan dengan kyai, santri, masjid, pondok, dan kitab kuning. Pesantren menjadi lembaga yang efektif untuk membentuk dan menyebarkan karakter bangsa yang sesuai dengan dasar Negara Indonesia (Yusuf, 2015). Kiprah pesantren di dalam bidang kenegaraan sangat signifikan sebagai 
lembaga sosial yang terus merespons persoalan masyarakat di sekitarnya.

Pondok pesantren dewasa ini telah berpartisipasi dalam mendukung santrinya untuk mengembangkan IPTEK. Salah satunya adalah dengan menggunakan internet di dalam pondok. Dukungan infrastruktur jaringan komputer di Pondok Pesantren sangat memicu untuk untuk dikembangkannya keterampilan kepada santri. Salah satunya dengan membekali santri dalam kemampuan entrepreneur yaitu dengan memproduksi batik (Anwas, 2015).

Batik merupakan bagian dari budaya Indonesia yang berbentuk kerajinan dengan nilai seni tinggi yang diwariskan secara turun temurun (Trixie, 2020). Batik menjadi seni dan kerajinan yang telah ada selama berabad-abad dan merupakan bagian dari tadisi kuno. Motif dan warna batik beraneka ragam sesuai dengan filosofi dan kelompok masyarakat yang mengembangkannya. UNESCO sebagai lembaga pada PBB yang berkaitan dengan kebudayaan sejak Oktober 2009 telah menetapkan batik sebagai warisan budaya Indonesia yaitu Masterpiece of The Oral and Intangible of Humanity (Indah Purnama dkk., 2019). Seiring perkembangan zaman, batik yang awalnya hanya berupa batik tulis mengalami perkembangan dengan munculnya jenis batik baru, yaitu batik ikat celup, batik cap, batik printing dan batik sablon. Pembuatan batik tulis dilakukan dengan membuat motif pada kain dengan cara menutupi bagian-bagian tertentu menggunakan malam yang dimasukkan kedalam canting (Kustiyah, 2017).

Desain batik dapat dilakukan dengan menggunakan beberapa software yang akan sangat membantu peserta didik dalam membuat batik selanjutnya (Trixie, 2020). Desain dapat dilkukan dengan menggunakan CoreIDRAW. Dasar-dasar dalam menggunakan CorelDRAW harus terlebih dahulu dipahami dan dipelajari peserta didik, sehingga kelak ketika akan melanjutkan dengan desain batik yang beraneka ragam akan lebih mudah. Pada sub bab selanjutnya akan dijabarkan terkait lagkah-langkah untuk membuat desain batik menggunakan CoreIDRAW.

Selain itu pengetahuan mengenai simulasi bisnis juga mutlak diberikan (Poltak et al., 2021). Dengan memberikan materi simulasi bisnis kepada santri, santri terlebih dahulu memiliki gambaran untuk memulai usahanya. Yang paling penting adalah terus kreatif berinovasi. Pelatihan desain juga bertujuan agar santri dapat kreatif mendesain batik atau merek dagangan mereka, serta kemasannya. Pengetahuan bahwa sistem penjualan yang telah berkembang melalui media sosial dan blog maupun website juga perlu diutarakan dan disampaikan kepada santri. Selain itu santri juga diberi pengetahuan serta keterampilan mendesain blog untuk berjualan online.

Motif atau desain batik yang dikembangkan adalah batik dengan motif sains yang nantinya bisa menjadi ciri khas daerah Jombang yang tercipta dari tangan santri Pondok Pesantren Babussalam Jombang. Pelatihan ini dilaksanakan dengan harapan mampu mewujudkan cita-cita pemerintah daerah yaitu pesantren dapat memperkuat program-program pemerintah daerah dalam mendorong kemandirian perekonomian pesantren semisal One Pesantren One Produk (OPOP) yang digagas Pemprov Jawa Timur (Setiawan, 2020). Pelatihan ini bertujuan khusus untuk membekali santri Pondok Pesantren Babussalam Kecamatan Mojoagung Kabupaten Jombang dengan pengetahuan bisnis dan aplikasi komputer yang banyak dibutuhkan dalam berwirausaha maupun sebagai tenaga kerja pada perusahaan maupun instansi. Aktivitas yang dilakukan untuk mencapai tujuan tersebut adalah dengan memberikan berapa pelatihan kewirausahaan yaitu: batik sains beserta simulasi bisnisnya, Pelatihan desain dengan CorelDraw tingkat Pemula serta Pelatihan Blog desain yang bertujuan untuk dapat melakukan pemasaran online melalui blog.

\section{METODE}

Pelaksanaan kegiatan pengabdian ini dilaksanakan di Pondok Pesantren Babussalam Kecamatan Mojoagung Kabupaten Jombang antara bulan Juni hingga Juli. Pelaksanaan pengabdian dilaksanakan di tengah suasana pandemi COVID-19, penerapan prokes sangat ketat dan disiplin. Peserta pelatihan diukur suhu tubuhnya, dibagikan masker, faceshield dan diberikan hand sanitizer sebelum memasuki ruang acara.

Ada dua pelatihan yang dilaksanakan pada santri Pondok Pesantren Babussalam yaitu Pelatihan pembuatan Desain Batik Menggunakan CorelDraw dan dilanjutkan Pelatihan Pembuatan Desain BlogSpot. Kedua Pelatihan diikuti oleh santriwan-santriwati Pondok Pesantren Babussalam sejumlah 40 orang. Pelaksanaan pelatihan menggunakan tahapan metode sebagai berikut:

a. Ceramah dan tanya jawab, untuk menjelaskan dasar-dasar pembuatan desain menggunakan software CorelDraw.

b. Demonstrasi untuk menjelaskan suatu penciptaan desain batik menggunakan software CorelDraw. Dengan demikian peserta dapat mengamati secara langsung cara mendesain 
dan memperaktekkan secara langsung dengan pendampingan tutor menggunakan software CorelDraw.

c. Ceramah dan tanya jawab, untuk menjelaskan dasar-dasar pembuatan e-mail dan blogspot.

d. Demonstrasi pembuatan e-mail dan blogspot untuk masing-masing peserta dengan didampingi tutor.

Tabel 1. Bentuk Partisipasi dalam Pelaksanaan Kegiatan

\begin{tabular}{ll}
\hline $\begin{array}{l}\text { Yang Disiapkan } \\
\text { PP Babussalam }\end{array}$ & $\begin{array}{l}\text { Yang Disiapkan UPN } \\
\text { "Veteran" JT }\end{array}$ \\
\hline Ruang Aula & $\begin{array}{l}\text { Modul CorelDraw dan } \\
\text { Blogspot }\end{array}$ \\
\hline $\begin{array}{l}\text { Peserta sejumlah } \\
\text { 40 santri Aliyah }\end{array}$ & Spanduk (BackDrop) \\
\hline LCD dan Layar & Sertifikat \\
\hline Speaker/audio & Plakat (Merchandise) \\
\hline Meja Kursi & Konsumsi (Minuman, \\
peserta dan & Snack, makan) \\
Pemateri & Kuisoner, PPT \\
\hline 40 Laptop & $\begin{array}{l}\text { Dokumentasi\&Publikasi } \\
\text { (Youtube) }\end{array}$ \\
\hline Wifi & $\begin{array}{l}\text { Sertifikat Best Design, } \\
\text { Thermogan, }\end{array}$ \\
\hline Wastafel & Cucindsanitizer, Masker \\
tangan & Medis, Face shield \\
\hline Software & Blocknote dan Bolpoin \\
CorelDraw & $\begin{array}{l}\text { Absensi Rangkap 3 tiap } \\
\text { Membentuk }\end{array}$ \\
Panitia Pondok acara (Sambutan, \\
\end{tabular}

\section{HASIL DAN PEMBAHASAN}

Dua Pelatihan ini dilaksanakan pada hari Sabtu tanggal 3 Juli 2021 mulai pukul 08.00 hingga pukul 16.00 WIB. Dewan Pengasuh, ustadz Pondok Pesantren Babussalam, dan pembimbing pelatihan hadir dalam kegiatan pembukaan. Pembukaan diawali oleh laporan ketua pelaksana pengabdian masyarakat. Pada laporan disampaikan bahwa maksud dari kegiatan pelatihan adalah untuk meningkatkan kemampuan softskill dibidang desain batik menggunakan software CorelDrraw santriwansantriwati dan dapat berwirausaha memberikan nilai tambah pada hasil produk sendiri. Terkhusus, dalam tujuan utama Pengabdian Masyarakat yang dilakukan oleh UPN Veteran Jawa Timur agar terjalin silaturahim antara pihak kampus dengan pondok pesantren di Jombang. Hal ini demi mewujudkan cita-cita besar Gubernur Jawa Timur Khofifah Indar Parawansa yang mengatakan, program One Pesantren One Product (OPOP) akan menjadi salah satu pilar kuat dalam perekonomian jawa timur. Mulai dari kategori top 10 halal food, muslim friendly travel, fashion, finance maupun kosmetik dan obat-obatan. Ketua pelaksana selanjutnya membuka acara yang didahului memberikan arahan. Dalam arahannya, ketua pelaksana pelatihan desain membatik ini kemudian dipetakan untuk menyusun langkah pembinaan OPOP di Pondok Pesantren Babussalam yang akan dipikirkan mulai dari SDM, kualitas produk, pembiayaan dan pemasaran. Ketua pelaksana juga menyampaikan peran UPN Veteran Jawa Timur sebagai lembaga pendidikan vokasi untuk menciptakan wirausaha sesuai dengan Indikator Kinerja Utama yang menjadi target dari Unit Pelaksana teknis.

Selesai arahan dan pembukaan ketua pelaksana dilanjutkan kepada sambutan Dewan Pengasuh Pondok Pesantren Babussalam. Dalam sambutannya, Pondok Pesantren Babussalam menyambut baik kedatangan UPN Veteran Jawa Timur. Dan berharap para santri nantinya mendapatkan ilmu serta ketrampilan entrepreneur, sehingga mampu menjawab tantangan kemajuan zaman saat ini. Kemajuan Teknologi sudah tidak bisa dihindari lagi. Sehingga para santri harus mampu membekali diri selain ilmu agama juga ilmu Teknologi dan Informasi. Selesai arahan dari Dewan Pengasuh Pondok Pesantren Babussalam dilanjutkan pelatihan pertama. Pelatihan ini dimulai dengan materi-materi dasar penggunaan software CorelDraw dan dan penganalan tools untuk mendesain bentukbentuk sederhana kepada coach dan pendamping.

Tabel 2. Jadwal Pelatihan Desain Batik pada Santri Pondok Pesantren Babussalam

\begin{tabular}{|c|c|}
\hline Waktu Acara (WIB) & Susunan Acara \\
\hline \multirow[t]{6}{*}{$09.00-09.30$} & Pembukaan \\
\hline & $\begin{array}{l}\text { Pembacaan Ayat } \\
\text { Suci Al-Qur'an }\end{array}$ \\
\hline & $\begin{array}{l}\text { Sambutan Ketua } \\
\text { PIKAT }\end{array}$ \\
\hline & Sambutan Ketua \\
\hline & $\begin{array}{ll}\text { Yayasan } & \text { PP } \\
\text { Babussalam } & \end{array}$ \\
\hline & Doa dan Penutup \\
\hline $09.30-10.30$ & Pembelajaran Corel \\
\hline & $\begin{array}{l}\text { Draw Desain Batik } \\
\text { Sains }\end{array}$ \\
\hline $10.30-10.40$ & Coffe Break \\
\hline $10.40-12.00$ & Pelatihan \\
\hline & $\begin{array}{l}\text { Draw Desain Batik } \\
\text { Sains }\end{array}$ \\
\hline $12.00-13.00$ & ISHOMA \\
\hline $13.00-13.30$ & $\begin{array}{l}\text { Pembelajaran dan } \\
\text { Desain Blogspot }\end{array}$ \\
\hline $13.30-13.40$ & Coffe Break \\
\hline $13.40-15.00$ & $\begin{array}{l}\text { Pelatihan } \\
\text { Pembuatan } \\
\text { Blogspot }\end{array}$ \\
\hline
\end{tabular}


Pada sesi pertama, peserta diberikan pengetahuan tentang dasar desain grafis. Materi desain grafis diberikan dengan tujuan untuk memberikan pengetahuan tentang bagaimana mengelola titik, garis, bentuk, huruf, symbol, citra (image), ruang, tekstur, dan warna dengan baik. Materi yang diberikan berisi tentang pengertian desain grafis, unsur desain grafis, kombinasi unsur desain grafis, komposisi desain grafis, dan layout (tata letak). Materi ini disampaikan oleh Dr. Nur Aini Fauziyah, S.Pd., M.Si. Pada sesi kedua, peserta diberikan kesempatan untuk merancang berbagai desain batik secara manual. Proses ini merupakan tahap awal peserta dalam membuat desain batik. Dari hasil tahap ini, peserta akan mendapatkan desain batik manual dengan warna hitam putih yang akan didigitalisasi setelah coffe break. Sesi selanjutnya adalah pendampingan mendesain batik secara digital dipandu oleh tutor oleh Radissa Dzaky Issafira, S.T., M.Sc dan Syahrul Munir, S.T., M.T. Materi pertama ini adalah proses penciptaan ide kreatif. Pemberian materi ini dianggap penting oleh sebagai bekal menuju tingkat desain batik lebih lanjut. Materi ini diberikan dengan menggunakan metode ceramah, diskusi plus tugas. Pendampingan menggunakan metode ceramah, diskusi, dan tugas dapat dilihat pada Gambar 1.

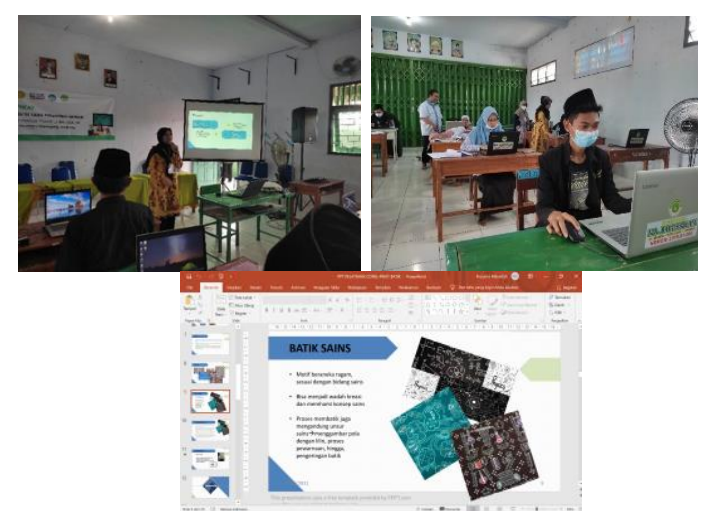

Gambar 1. Dokumentasi Pendampingan Desain Batik Menggunakan Software CorelDraw
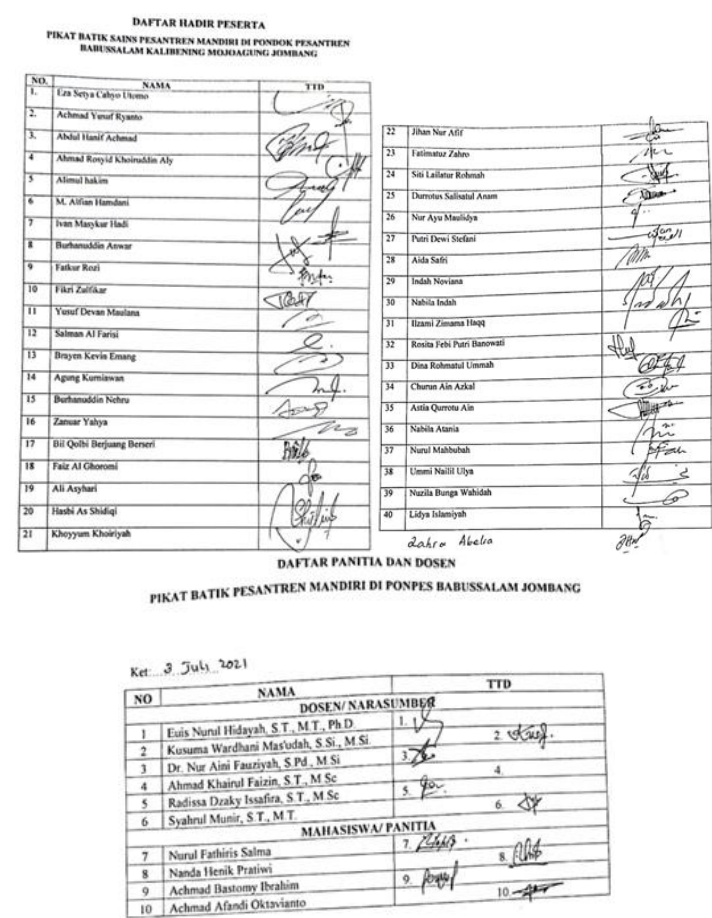

Gambar 2. Daftar Hadir Peserta Acara di Pondok Pesantren Babussalam

Setelah waktu istirahat, sholat dan makan (Ishoma), para peserta mengisi daftar hadir yang telah disediakan setiap kali memasuki ruangan yang dapat dilihat pada Gambar 2. Kemudian dilanjutkan acara sesi kedua yaitu pelatihan pembuatan blogspot. Pada Pelatihan Blog Desain, santri diberikan materi tentang pengenalan blog, apa itu blog, wawasan penjualan melalui media sosial, mendesain blog untuk keperluan promosi dan penjualan online. Materi ini disampaikan oleh Kusuma Wardhani Mas'udah, S.Si., M.Si. Materi Tutorial pembuatan blog menggunakan blogspot (blogger) sebagai tempat pembuatannya didahului tutorial pembuatan satu alamat e-mail dikarenakan belum ada santriwan-santriwati Pondok Pesantren Babuusalam yang memiliki e-mail. Karena syarat utama membuat blog di blogspot adalah alamat e-mail di gmail. Pemberian materi ini dianggap penting sebagai bekal menuju ketingkat yang lebih lanjut untuk dapat melakukan pemasaran online melalui blog. Materi ini diberikan dengan menggunakan metode ceramah, diskusi dan praktek. Pendampingan menggunakan metode ceramah, diskusi, dan praktek dapat dilihat pada Gambar 3. 


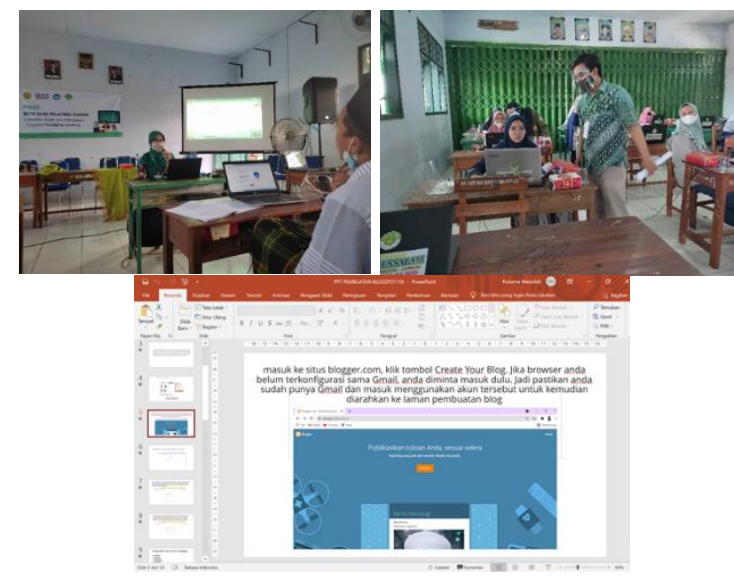

Gambar 3. Dokumentasi Pendampingan Pembuatan e-mail dan Blog

\section{SIMPULAN DAN SARAN}

Dari pelaksanaan kegiatan

Pengabdian Kepada Masyarakat untuk santri pondok pesantren Babbussalam melalui digitalisasi desain batik dan pemasaran digital, dapat disimpulkan beberapa hal sebagai berikut: a) Peserta pelatihan merasa pengetahuan tentang dasar-dasar desain grafis mereka meningkat terbukti dari hasil post test yang meningkat, b) Peserta mampu mendigitalisasi desain batik menjadi lebih menarik, dan c) Peserta pelatihan mampu menggunakan software desain grafis untuk memperindah tampilan desain batik yang telah dibuat yaitu Corel Draw. Berdasarkan hasil kegiatan pengabdian masyarakat yang telah dilaksanakan memberikan banyak manfaat, maka saran untuk kegiatan selanjutnya adalah sebagai berikut: 1) Diharapkan kegiatan ini dapat menjadi program keberlanjutan, dengan pengembangan usaha batik khas daerah Jombang, dan 2) Adanya monitoring dan aspek keberlanjutan program pasca pengabdian masyarakat ini sehingga diharapkan peserta yang mengikuti pelaksanaan kegiatan ini dapat tetap mempraktekan materi yang telah diberikan.

\section{UCAPAN TERIMAKASIH}

Pelaksanaan kegiatan Pengabdian Kepada Masyarakat ini telah melibatkan berbagai pihak, oleh karena itu pada kesempatan ini kami mengucapkan terima kasih dan penghargaan kepada:

1. LPPM Universitas Pembangunan Nasional "Veteran" Jawa Timur selaku koordinator pelaksanaan pengabdian kepada masyarakat yang telah mendukung dan mendanai riset ini melalui Hibah skema pengabdian kepada masyarakat Program Pemanfaatan Ipteks Bagi Masyarakat (PIKAT) Batch 2 bagi Dosen Baru
Tahun Anggaran 2021 Nomor:SPP/ 64 /UN.63.8/DIMAS/V/2021 dengan judul "Pikat Batik Sains Pesantren Mandiri Di Pondok Pesantren Babussalam Jombang".

2. Fakultas Teknik Universitas Pembangunan Nasional "Veteran" Jawa Timur yang telah banyak membantu penelitian ini.

3. Dewan Pengasuh Pondok Pesantren Babussalam Kalibening Kecamatan Mojoagung Kabupaten Jombang.

\section{DAFTAR RUJUKAN}

Anwas, O. M. (2015) 'Pemanfaatan Teknologi Informasi dan Komunikasi pada Pesantren Rakyat Sumber Pucung Malang', Jurnal Pendidikan dan Kebudayaan, 21(3), p. 207. doi: 10.24832/jpnk.v21i3.187.

Indah Purnama Sari, Siswi Wulandari, S. M. (2019) 'Urgensi Batik Mark Dalam Menjawab Permasalahan Batik Indonesia ( Studi Kasus Di Sentra Batik Tanjung Bumi) Program Studi Pendidikan Ekonomi, Fakultas IImu Pendidikan Dan Pengetahuan Sosial, Universitas Indraprasta Pgri', Universitas Indraprasta PGRI, 11(1), pp. 16-27. Available https://www.mendeley.com/catalogue/12 5b1dc0-b2d3-3219-af1d-29c9f8139d10/.

Kustiyah, I. E. (2017) 'Batik Sebagai Identitas Kultural Bangsa Indonesia Di Era Globalisasi', Gema, 30(52).

Poltak, H. et al. (2021) 'Pendampingan Kelompok Kewirausahaan Muda bagi Pemula Bidang Kelautan dan Perikanan di Politeknik Kelautan dan Perikanan Sorong', Selaparang. Jurnal Pengabdian Masyarakat Berkemajuan, 4(April), pp. 96-103.

Senoprabowo, A., Muqoddas, A. and Hasyim, N. (2019) 'Desain Grafis untuk Meningkatkan Nilai Kaligrafi pada Santri dan Pengurus Pondok Pesantren Al-Hadi Kabupaten Demak', International Journal of Community Service Learning, 3(4), p. 211. doi: $10.23887 /$ ijcsl.v3i4.21792.

Setiawan, W. L. (2020) 'Program One Pesantren One Product Dapat Menjadi Pendekatan Akselerasi Bisnis Di Pesantren Pada Masa Pandemi Covid19', E-Coops-Day, 1(2), pp. 57-64.

Trixie, A. A. (2020) 'Filosofi Motif Batik Sebagai Identitas Bangsa Indonesia', Folio, Vol 1 No 1, pp. 1-9. Available at: https://journal.uc.ac.id/index.php/FOLIO/ article/view/1380.

Yusuf, M. Y. (2015) 'Pesantren Sains: 
Epistemology of Islamic Science in Teaching System', Walisongo: Jurnal Penelitian Sosial Keagamaan, 23(2), p. 283. doi: 10.21580/ws.23.2.280. 